\title{
DEVELOPMENT OF A MODEL OF THE ACUTE AND DELAYED EFFECTS OF HIGH DOSE RADIATION EXPOSURE IN JACKSON DIVERSITY OUTBRED MICE; COMPARISON TO INBRED C57BL/6 MICE
}

Andrea M. Patterson ${ }^{1 *}$, P. Artur Plett ${ }^{1 *}$, Hui Lin Chua ${ }^{1}$, Carol H. Sampson ${ }^{1}$, Alexa Fisher ${ }^{1}$, Hailin Feng ${ }^{1}$, Joseph L. Unthank ${ }^{1}$, Steve J. Miller ${ }^{1}$, Barry P. Katz ${ }^{1}$, Thomas J. MacVittie ${ }^{2}$, Christie M. Orschell $^{1}$

\section{CORRESPONDING AUTHOR:}

Name: $\quad$ Christie M. Orschell

Address: $\quad 980$ W. Walnut St., R3-C341, Indianapolis, IN, 46202.

Phone: $\quad 317-278-2834$

Fax: $\quad 317-274-0396$

Email: $\quad$ corschel@iupui.edu

\section{CONFLICTS OF INTEREST AND SOURCES OF FUNDING:}

The authors have no conflicts of interest to declare.

This project has been funded in whole or in part with federal funds from the National Institute of Allergy and Infectious Diseases, National Institutes of Health, Department of Health and Human Services under contracts HHSN266200500043C and HHSN272201000046C.

\section{FOOTNOTES:}

${ }^{1}$ Department of Medicine, Indiana University School of Medicine, Indianapolis, IN ${ }^{2}$ Department of Radiation Oncology, University of Maryland School of Medicine, Baltimore, MD *these authors contributed equally to the work.

This is the author's manuscript of the article published in final edited form as:

Patterson, A. M., Plett, P. A., Chua, H. L., Sampson, C. H., Fisher, A., Feng, H., Unthank, J. L., Miller, S. J., Katz, B. P., MacVittie, T. J., \& Orschell, C. M. (2020). Development of a Model of the Acute and Delayed Effects of High Dose Radiation Exposure in Jackson Diversity Outbred Mice; Comparison to Inbred C57BL/6 Mice. Health Physics, 119(5), 633-646. https://doi.org/10.1097/HP.0000000000001344 


\begin{abstract}
Development of medical countermeasures against radiation relies on robust animal models for efficacy testing. Mouse models have advantages over larger species due to economics, ease of conducting aging studies, existence of historical databases, and research tools allowing for sophisticated mechanistic studies. However, the radiation Dose Response Relationship of inbred strains is inherently steep and sensitive to experimental variables, and inbred models have been criticized for lacking genetic diversity. Jackson Diversity Outbred (JDO) mice are the most genetically diverse strain available, developed by the Collaborative Cross Consortium using eight founder strains, and may represent a more accurate model of humans than inbred strains. Herein, models of the Hematopoietic-Acute Radiation Syndrome and the Delayed Effects of Acute Radiation Exposure were developed in JDO mice and compared to inbred C57BL/6. The Dose Response Relationship curve in JDO mice mirrored the more shallow curves of primates and humans, characteristic of genetic diversity. JDO mice were more radioresistant than C57BL/6, and differed in sensitivity to antibiotic countermeasures. The model was validated with pegylatedG-CSF, which provided significantly enhanced 30-day survival and accelerated blood recovery. Long-term JDO survivors exhibited increased recovery of blood cells and functional bone marrow hematopoietic progenitors compared to C57BL/6. While JDO hematopoietic stem cells declined more in number, they maintained a greater degree of quiescence compared to C57BL/6, which is essential for maintaining function. These JDO radiation models offer many of the advantages of small animals with the genetic diversity of large animals, providing an attractive alternative to currently available radiation animal models.
\end{abstract}

Key words: Health effects (radiation effects), mice, whole body irradiation, bone marrow 


\section{INTRODUCTION}

High dose radiation exposure of 2-10 Gy leads to the hematopoietic-acute radiation syndrome (H-ARS) and the delayed effects of acute radiation exposure (DEARE) in survivors of H-ARS. Efficacy testing for medical countermeasures (MCM) against H-ARS must be conducted in relevant animal models according to the Food and Drug Administration (FDA) Animal Rule (Crawford 2002). Mice are the most common animal model for H-ARS and DEARE studies for several reasons: the existence of a relatively large database that spans decades, availability of substantial research tools that allow for sophisticated mechanistic studies, ease of housing and handling, economics, minimal ethical considerations, ability to conduct aging studies, existence of congenic strains allowing for interrogation of hematopoietic stem and progenitor cell (HSPC) function, and the ease of conducting screening studies, dose- and schedule-finding studies, and pharmacokinetic/pharmacodynamic studies prior to assessment in large animal models. However, inbred mice, due to their genetic homogeneity, can be challenging for conducting $\mathrm{H}$ ARS studies due to their steep radiation dose response relationship (DRR) curves (Baverstock and Ash 1983, Cerveny et al. 1989), where small changes in radiation dose can result in large changes in survival.

The recently developed Jackson Diversity Outbred (JDO) mouse strain is the most genetically diverse mouse strain available. JDO mice were derived by the Collaborative Cross Consortium by combining five existing laboratory-derived strains (A/J, C57BL/6J, 129/SvImJ, Non-obese diabetic (NOD/LtJ), New Zealand obese (NZO/HILtJ)), and three wild-derived strains (Castaneus Eicher (CAST/EiJ), PWK/PhJ, and Watkin Star Line B (WSB/EiJ) representing the three major Mus musculus subspecies (M. m. musculus, M. m. domesticus, and M. m. castaneous) (Churchill et al. 2004, Collaborative Cross 2012). These strains capture almost $90 \%$ of the known genetic variation originating from M. musculus (Roberts et al. 2007). Intercrossing and inbreeding these founder strains resulted in 175 breeding pairs, which are randomly mated three to four times per year in non-sibling matings, thereby further increasing the heterozygosity and number of genetic recombinations (Svenson et al. 2012). Due to their genetic heterogeneity, data from JDO mice studies are expected to be more variable, similar to human study data, with results more representative of the human population (Chesler 2014). Studies with JDO mice have already led to discovery of new genetic linkages to traits such as pain and activity/anxiety behavior (Logan et al. 2013, Recla et al. 2014), identification of variable susceptibility of individual mice to diseases such as tuberculosis (Niazi et al. 2015) as seen in human disease, and novel target identification in diabetes studies (Morton et al. 2016). For these reasons, the authors hypothesized that development of H-ARS and DEARE models in JDO mice would provide models 
more representative of the human population without the high cost and effort associated with large animal models (i.e., non-human primates, mini pigs, and canines) while retaining most of the advantages of rodent models.

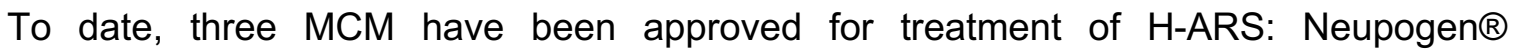
(granulocyte-colony stimulating factor, G-CSF), Neulasta ${ }^{\circledR}$ (pegylated G-CSF) and Leukine ${ }^{\circledR}$ (granulocyte-monocyte (GM)-CSF) (Singh and Seed 2020). Despite efficacy to significantly improve survival in H-ARS, none of these MCMs, nor any others to our knowledge, possess efficacy to reduce the devastating hematopoietic DEARE (Chua et al. 2014, Chua et al. 2019). Hematopoietic stem cell (HSC) quiescence, one of the hallmark properties of HSC, is essential to maintaining lifelong multi-lineage hematopoiesis and to preventing HSC functional depletion (Cheng et al. 2000, Hao et al. 2016). Loss of HSC quiescence in long-term H-ARS survivors, evidenced by significantly increased cell cycling compared to HSC from age-matched nonirradiated controls, is postulated to be a central causative factor for hematopoietic DEARE, as we have shown (Chua et al. 2012, Chua et al. 2019). Retention of HSC quiescence in H-ARS survivors may therefore contribute to improved health outcomes in DEARE.

The present work develops H-ARS and DEARE models in JDO mice and compares characteristics of these models to similar models developed by the authors in the inbred C57BL/6J (B6) mice (Plett et al. 2012, Unthank et al. 2015, Chua et al. 2019, Unthank et al. 2019), with respect to the radiation DRR curves, recovery of complete blood counts (CBC), effectiveness of MCM, severity of hematopoietic as well as cardiac and renal DEARE, and number and functional status of primitive HSPC phenotypically isolated from aged H-ARS survivors. The results described herein present new models for H-ARS and DEARE which may be more representative of the human population and more suitable than inbred models for assessing the natural history of radiation damage and MCM efficacy for more efficient development and approval of MCM for acute and delayed radiation injury. 


\section{MATERIALS AND METHODS}

\section{Mice and Husbandry}

Specific pathogen free C57BL/6J (B6) and JDO mice were received from Jackson Labs (50\%/50\% male/female; Jackson Laboratory, Bar Harbor, Maine). B6 mice were received at 10 weeks of age and acclimated for two weeks before irradiation at 12 weeks. JDO mice were received at 4 weeks of age due to vendor shipping requirements, and acclimated for 4 weeks before irradiation at 8 weeks. Age at irradiation was younger in the JDO model to avoid the economic impact of prolonged acclimation and development of aggression in this strain with age. Up to 5 mice per cage were housed in microisolator cages on sterilized, certified direct contact bedding (Alpha Dri) and provided certified commercial extruded lab rodent chow (Harlan 2018SXC) ad libitum in cage hoppers and acidified water ( $\mathrm{pH}$ 2.0-3.0) in sipper tube bottles. JDO males required single housing due to aggressive behavior. Mice were identified by ear punch and tail marks one week prior to irradiation. Autoclaved acidified water was provided on day 1 (d1) through d30 post-irradiation in sipper tubes and on d4-30 in wet feed. Animal rooms on a 12-hour light/dark cycle were maintained at $21 \pm 3^{\circ} \mathrm{C}$ with $30-80 \%$ relative humidity and at least 10 air changes per hour of $100 \%$ conditioned fresh air. After the 30 -day H-ARS phase was complete, surviving mice were transferred to standard corn-cob bedding, and non-acidified water purified by reverse osmosis from an automatic watering system. All studies were approved by the Indiana University School of Medicine Institutional Animal Care and Use Committee.

\section{Irradiation and dosimetry}

To construct radiation DRR curves for estimation of the LDXX/30, JDO mice were split into 12 radiation dose groups and each group exposed to a radiation dose between 8 to $11 \mathrm{~Gy}$ [total body irradiation (TBI)]. For the levofloxacin DRR, 16 groups of JDO mice were exposed to radiation doses between 8 and $14 \mathrm{~Gy}$. The DRR curves for JDO mice were constructed with data from 3 separate cohorts of 110-187 JDO mice each (407 mice total) and conducted over a 1-year period. The DRR for B6 mice was constructed as described previously (Plett et al. 2015) within the same year as the JDO DRRs. All irradiations utilized a stationary ${ }^{137} \mathrm{Cs}$ radiation source [Mark 1 Irradiator, JL Shepherd, San Fernando, California (1.01-1.03Gy $\left.\mathrm{min}^{-1}\right)$ ] with a rotating platform that supported the mice in individual compartments of a Plexiglas irradiation apparatus. For the Neulasta efficacy study, JDO mice were exposed to 9.0 Gy gamma radiation (0.99-1.0 Gy $\left.\mathrm{min}^{-1}\right)$. JDO and B6 mice for HSPC analyses during the DEARE phase were exposed to 9.48 Gy and $8.72 \mathrm{~Gy}$, the respective LD70/30 for each strain (0.88-0.89 Gy $\left.\mathrm{min}^{-1}\right)$. Mice were randomized to Vehicle or Neulasta groups individually within cages, or by cage for levofloxacin delivered in 
drinking water. JDO mice were also randomized into groups by coat color in both the DRR and the Neulasta studies.

Irradiations were performed between 8:00 and 11:00 AM to avoid chronoradiosensitivity effects described previously in our B6 model (Plett et al. 2012). Dosimetry was performed as previously described (Plett et al. 2012, Plett et al. 2015), which verified dose homogeneity in the exposure field of the mice to be $0.0-4.3 \%$ of calculated central dose, while mouse exposure was found to be within $10 \%$ of calculated dose as verified by Inlight nanodot dosimeters (Landauer Inc., Glenwood, IL) placed inside a parafilm or superflab mouse phantom which were irradiated along with the mice and read using a validated microStar reader that has an accuracy of $4 \pm 2 \%$.

\section{Drug administration}

Levofloxacin $\left(0.67 \mathrm{mg} \mathrm{mL}^{-1}\right)$ was provided on d1-30 post-irradiation in autoclaved acidified water ad libitum from sipper tubes and also on d4-30 in feed wetted with levofloxacin-containing autoclaved acidified water in Petri dishes set on the cage bottom. Controls received no antibiotics but did receive autoclaved acidified water and wet feed on the same schedule as levofloxacintreated mice. Irradiated female and male B6 mice consume approximately 0.115 and $0.105 \mathrm{~mL}$ water (g body weight) ${ }^{-1}$ day $^{-1}$, respectively [(Plett 2012) and unpublished observations]. Based on these data, levofloxacin dose is estimated to be $77 \mathrm{mg} \mathrm{kg}^{-1}$ day $^{-1}$ for females and $70 \mathrm{mg} \mathrm{kg}^{-1}$ day$^{-}$ ${ }^{1}$ for males. Neulasta (Besse Medical, West Chester, $\mathrm{OH}$ ) was administered subcutaneously at a dose of $1.0 \mathrm{mg} \mathrm{kg}^{-1} \mathrm{day}^{-1}$ at 24-25 $\mathrm{h}$ and on d8 post-TBI. Female and male mice were dosed based on the average weight of their respective sex obtained 7 days prior to irradiation. Control groups received saline $(0.9 \% \mathrm{NaCl}, \mathrm{w} / \mathrm{v})+0.1 \%$ bovine serum albumin (BSA, Fisher Scientific, Waltham, MA), or Plasmalyte-A (Baxter Healthcare Pty Ltd, Old Toongabbie, NSW).

\section{Health status monitoring}

Mice were observed and scored for health status daily from d1-30 post-irradiation, and twice daily once morbidity commenced. Three criteria for morbidity (severity of hunched posture, squinted/closed eyes, and decreased activity) were each scored on a scale of zero to three and used to determine need for humane euthanasia, as previously described (Plett et al. 2012). Although JDO mice are more heterogeneous in activity level than B6 mice, activity level of moribund mice of either strain becomes very low, so innate differences in activity between strains did not affect euthanasia decisions. Survivors after d30 were checked once daily. 


\section{Complete blood counts (CBC)}

Blood from tail-snips was collected in EDTA-coated tubes and analyzed on either an Element HT5 Veterinary Hematology Analyzer (Heska, Loveland, CO) or a HEMAVET® 950FS Hematology System (Drew Scientific, Waterbury, CT) within $2 \mathrm{~h}$ of collection. Attempts were made to analyze the same number of males and females in each group from different cages. Mice were bled a maximum of two times during the 30 -d survival study at least 14 days apart.

\section{BM cellularity and phenotyping}

Bone marrow cells were harvested and analyzed as whole BM or as low-density BM cells (LDBM) after density gradient centrifugation, as detailed in figure legends. For flow cytometry analyses, BM cells were stained with fluorophore-conjugated antibodies against lineage markers CD3, CD45R(B220) and Ly-G/Ly-6C for LDBM cells, and against lineage markers CD3, Ly-6G/Ly-6C, CD11b, CD45R/B220, and TER-119 for whole BM cells. Other fluorophore-conjugated antibodies against CD45, Sca1, cKit (CD117), CD150, CD48, IL7Ra (CD127), and FcGR (CD16/32) were from BD Biosciences (San Jose, CA) or Biolegend Inc. (San Diego, CA).

\section{Colony-forming unit cell (CFU-C) analyses}

Functional BM progenitor number was analyzed utilizing methylcellulose colony assays as per manufacturer instructions (Colony Gel 1202, ReachBio, Seattle, WA). Cultures were incubated in $100 \%$ humidified $5 \% \mathrm{CO}_{2}$ and $5 \% \mathrm{O}_{2}$ at $37^{\circ} \mathrm{C}$, and enumerated $7-9$ days later for total CFU-C colonies (CFU-GM, BFU-E, and CFU-GEMM) under a light microscope.

\section{Histochemistry}

Histochemical processing and analysis of heart and kidney tissue sections and blood urea nitrogen (BUN) were performed as previously described (Unthank et al. 2015, Unthank et al. 2019).

\section{Proliferation rate analysis}

BrdU incorporation assays were utilized to analyze cycling rates as described (Ashhurst et al. 2019). Briefly, $2 \mathrm{mg} \mathrm{BrdU}$ in $200 \mu \mathrm{L}$ PBS was injected twice, $24 \mathrm{~h}$ and $12 \mathrm{~h}$ prior to analysis. Following surface antibody staining, cells were fixed with $4 \%$ PFA, permeabilized in Cytofix/Cytoperm buffer (BD Biosciences) followed by Cytoperm Perm Buffer Plus (BD Biosciences), and re-fixed in Cytofix/Cytoperm buffer before a $1 \mathrm{~h}$ treatment with $2.4 \mathrm{mg} \mathrm{mL}^{-1}$ DNase I (titrated for lot). Finally, incorporated BrdU was stained with fluorophore-conjugated anti- 
BrdU antibody (Biolegend), and $0.3 \mu \mathrm{g} / \mathrm{mL}$ DAPI was added prior to flow cytometry. Samples were acquired on a BD LSR II flow cytometer and analyzed using FlowJo software.

\section{Statistical analyses}

Statistical analysis of 30-day survival was conducted using logistic regression as previously described (Plett et al. 2012). Analyses also included cage effects, gender, radiation dose and interactions of treatment with dose, gender, weight, and coat color (in the case of JDO mice) to examine differential effects. Neulasta survival studies were powered to detect a $30 \%$ reduction in mortality with $80 \%$ power using a two-tailed $5 \%$ significance level. Body weight, CBC, progenitor colonies, percentage and number of hematopoietic progenitors or stem cells and BrdU+ fractions were analyzed using 2-tailed unpaired student t-tests. 


\section{RESULTS}

\section{Characterization of JDO mouse weight, coat color, behaviors, and CBC}

JDO mice present with various coat colors that were categorized into black ( 13\%), white ( 19\%), and various shades of agouti grouped as "brown" ( $68 \%$, including brown, fawn, peach, with and without white spots on the forehead or abdomen). JDO mice had varying individual behaviors as noted previously (Svenson et al. 2012), where some mice startled easily leading them to jump out of cages when handled, some were docile and easily handled, while others were very active and aggressive. Male JDO mice were more aggressive than B6 males, requiring the vendor to ship them around 4-5 weeks of age to allow for group shipment without fighting. Their aggressive behavior led to fighting and wounding even after irradiation when most strains become lethargic, necessitating JDO males to be single housed upon receipt. Increased aggression and single housing of males adds a level of difficulty and expense which must be weighed against the advantages of this model for a given application, but for representing human genetic diversity JDO mice still outcompete larger models like mini-pigs and non-human primates in regard to cost and ease of use.

Body weights of JDO mice were more variable than those of B6 mice (Fig. 1a), and evenly distributed across the different coat colors (data not shown). To avoid significant costs associated with prolonged acclimation, as well as increasing aggressivity with age, the JDO H-ARS model was established in mice at 8 weeks of age (after 3-4 weeks of acclimation), whereas the B6 $\mathrm{H}$ ARS model was established at 12 weeks of age (after 2 weeks of acclimation). Weights of 7week-old JDO mice were on average significantly greater than those of 11-week-old B6 mice for both sexes, despite a larger range in both directions (Fig. 1a).

CBC values of 8-week-old JDO mice (Fig. 1b-f) closely resembled previously published values for 10-week-old JDO mice (Svenson et al. 2012). Peripheral blood (PB) concentrations of total white blood cells (WBC) and lymphocytes (LY) were slightly but significantly lower in 8-weekold JDO mice compared to 12-week-old B6 mice for both sexes. JDO females had lower neutrophils (NE) and platelets (PLT) than JDO males, and JDO males had higher red blood cells (RBC) compared to B6 males (Fig. 1b-f). As expected, JDO mice exhibited greater variability in all CBC parameters compared to $\mathrm{B} 6$ mice.

\section{Radiation Dose Response Relationship}

Probit plots of JDO versus B6 mice showed increased radioresistance of JDO mice, with an estimated LD50/30 of 9.00 Gy for JDO and 8.53 Gy for B6 mice (Fig. 2a). Despite the wide genetic diversity within the JDO model, the $95 \%$ confidence interval of the LD estimates did not 
overlap between JDO and B6 in the estimated range of LD50/30 and above (data not shown). The B6 DRR curve had a much steeper slope (2.56) compared to that of the outbred JDO mice (1.02), which is close to the slope of 1.13 for rhesus macaques (Farese et al. 2012) and consistent with genetic heterogeneity (Cerveny et al. 1989). The different slopes are reflected in the greater radiation dose range between the LD30/30 and LD90/30 in JDO (1.77 Gy) compared to B6 mice (0.7 Gy).

Delivery of the broad spectrum antibiotic levofloxacin (REMM 2013) to JDO mice ad libitum in drinking water significantly increased 30-day survival and mean survival time (MST) by 1.9 days ( 14.0 to 15.9 days) at radiation doses greater than $8.75 \mathrm{~Gy}(\mathrm{p} \leq 0.03$ ) and overall survival at doses greater than 9.0 Gy (p<0.004) (Fig. 2b). Levofloxacin further reduced the slope (0.69), and increased the LD50/30 from 9.00 Gy to $9.62 \mathrm{~Gy}$. As we previously reported, levofloxacin did not increase 30-day survival in B6 mice but did significantly increase mean survival time (Plett et al. 2012), suggesting differences in antibiotic sensitivities between strains.

Both female JDO mice and female B6 mice exhibited significantly better survival than males of the same strain $(p<0.01)$ in the DRR study. Within each sex, JDO mice with higher baseline body weight showed significantly improved $30 \mathrm{~d}$ and overall survival $(p \leq 0.006)$ than lighter weight mice. Also, black JDO mice had significantly greater odds of death than both brown mice and white mice ( $p=0.0494$ and $p=0.0185$, respectively) with lower $30 d$ survival, but the coat color effect was minimal and did not reach significance for overall survival.

\section{Short-term hematopoietic recovery}

Peripheral blood NE, RBC, and PLT counts in irradiated (IR) JDO mice at day 30 of the survival study had recovered to levels seen in non-IR $(\mathrm{NI})$ controls, while $\mathrm{LY}$ remained significantly lower, resulting in lower overall WBC levels ( $p<0.007$ vs. NI, Fig. 3a-e). The incomplete LY recovery at d30 is similar to results in inbred mice in our lab and that of others (Plett et al. 2012, Park et al. 2014, Plett et al. 2014). Evaluation of BM hematopoietic cells at d35 showed no significant difference in total mononuclear cells (Fig. 3f), but the primitive compartment defined as lineage marker-negative (Lin-), cKit+ and Sca1+ (KSL) remained depleted in IR JDO mice (Fig. $3 \mathrm{~g})$. The percentage of CD150+ cells in the KSL population was statistically increased in IR JDO mice (Fig. 3h), similar to other reports (Simonnet et al. 2009, Chua et al. 2012, Chua et al. 2019), but the absolute number of KSL CD150+ cells was similar between NI and IR JDO mice (Fig. 3i). Spleen weight was not significantly different between IR and NI mice (data not shown). 


\section{Survival with Neulasta treatment}

A crucial step in validating JDO mice as an H-ARS model suitable for efficacy testing of MCM was to examine the effectiveness of a known radiomitigator. Our laboratory previously reported that one to two doses of the approved H-ARS radiomitigator Neulasta (pegylated G-CSF) significantly increased survival in lethally irradiated B6 mice (Chua et al. 2014). To assess efficacy in JDO mice, mice were exposed to $9.0 \mathrm{~Gy}$, the LD50/30, and administered two doses of Neulasta at 24$25 \mathrm{~h}$ and $8 \mathrm{~d}$ after exposure. Results from two separate experiments demonstrate that Neulasta treatment significantly increased survival by an average of $43.6 \%$ compared to vehicle-treated mice ( $p<0.0001$ for 30 -day and overall survival, Fig. 4a). In this study, increased 30-day survival was not statistically correlated with sex or weight $(p=0.5356$ and $p=0.8035$, respectively, by logistic regression analysis). Survival among vehicle-treated mice that were black, brown, or white was $35 \%, 33 \%$, and $31 \%$, respectively, and was not significantly different $(p=0.8862)$.

Kinetics of CBC depletion and recovery were tracked in JDO mice during the H-ARS phase to establish whether increased survival with Neulasta correlates with improved peripheral blood cell recovery. Similar to B6 mice (Plett et al. 2012), as well as non-human primates (MacVittie et al. 2014, Farese et al. 2015), the leukocyte nadirs were reached around day 5-10, while those of RBC and PLT occurred slightly later (Fig. 4b-f). The rate of decline to nadir was similar in Neulasta- and vehicle-treated mice for all CBC parameters. However, NE and RBC recovery was significantly accelerated in Neulasta-treated mice, similar to B6 mice (Plett et al. 2012). PLT levels also trended towards slightly faster recovery in Neulasta-treated mice, but did not reach significance. Thus, the JDO H-ARS model appears to replicate the hematopoietic response to granulopoietic radiomitigators similar to other H-ARS models.

\section{DEARE in JDO survivors}

Hematopoietic, renal, and cardiac DEARE were investigated at 6 and 12 months post-TBI in Vehicle- and Neulasta-treated $\mathrm{H}-\mathrm{ARS}$ survivors in comparison to $\mathrm{NI}$ age-matched controls. Body weights of both female and male Vehicle- and Neulasta-treated IR mice trended lower than $\mathrm{NI}$ age-matched controls (Fig. 5a-b), similar to our previous report for B6 H-ARS survivors (Chua et al. 2012, Chua et al. 2014). Spleen weights were comparable between all groups (data not shown).

In contrast to B6 mice where all CBC parameters were significantly decreased in the DEARE phase (Chua et al. 2019), in JDO H-ARS survivors, WBC, LY, and NE were not different between IR and NI mice at 6 or 12 mo post-TBI (Fig. 5c-e). Average RBC and PLT counts were 
slightly lower at 12 mo in IR JDO mice, reaching significance only in the vehicle group for RBC, and in the Neulasta group for PLT (Figure 5f-g).

Total low-density BM cellularity was also similar between NI and IR JDO mice at both time points (Fig. 5h). However, number of colony forming unit-cells (CFU-C), indicative of functional progenitors, as well as KSL and KSL CD150+ cells, were lower in IR JDO compared to NI, significantly at 6 mo post-TBI for CFU-C and KSL (Fig. 5i-j, 5I). CFU-C, KSL, and KSL CD150+ also declined with age in NI JDO mice (Fig. 5i-j, 5I). Similar results for CFU-C, KSL, and KSL CD150+ cells have been reported in NI and IR B6 mice (Chua et al. 2012, Chua et al. 2014). The percentage of CD150+ cells of KSL cells did not differ between NI and IR JDO (Fig. 5k), in contrast to the pattern in $\mathrm{B} 6$ mice where percentage of CD150+ cells increased after irradiation (Chua et al. 2019).

The authors have previously reported loss of coronary arterioles and significantly increased blood urea nitrogen (BUN) in long-term H-ARS B6 survivors, documenting multi-organ DEARE in the B6 model (Unthank et al. 2015, Unthank et al. 2019). Similarly, JDO H-ARS survivors exhibited typical cardiovascular and renal pathology, but with greater variation between individual mice than previously reported in inbred B6 mice. In the kidney, JDO mice 12 mo postTBI exhibited a range from near normal pathology to increased collagen deposition in glomeruli, and both glomerular and tubular atrophy, which are typical characteristics of radiation nephropathy (Fig. 6a-b). Coronary arteries of IR JDO mice had variable adventitial and medial layer collagen deposition and endothelial cell loss, characteristics of radiation vasculopathy (Fig. 6c-f). Hemosiderin deposition observed by Perl's staining was consistent with the accumulation of iron in macrophages and was present in coronary arteries of all JDO mice (Fig. 6 g-j), suggesting the observed fibrosis and endothelial cell loss may be iron-induced. Perls' staining has also been reported in renal tubules of kidneys after irradiation, as seen here to varying degrees (Fig. 6k-I). BUN values for these mice were also quite variable and while BUN was markedly increased in IR mice, no difference was noted between Vehicle and Neulasta groups (Fig. 6m). The $\mathrm{NI}$ mean value was comparable to that previously measured in B6 from 4-21 months of age (Unthank et al. 2015) and also that reported for 6-12 month old male B6 (Frith et al. 1980). NI JDO at 8 months of age had a mean BUN of $21.4 \pm 1.4(n=4)$, similar to that at 15 months of age (mean BUN of $22.6 \pm 1.6$, Fig. $6 \mathrm{~m}$ ), indicating no effect of aging over this time.

\section{Direct Comparison of RBMD in JDO and B6 Models}

Data described thus far comparing the DEARE in JDO mice to that in B6 mice used our historical DEARE data for B6 mice (Chua et al. 2014, Chua et al. 2019). Given the observed differences, it 
was prudent to conduct a direct comparison of hematopoietic parameters in JDO and B6 longterm survivors of H-ARS to validate and strengthen these findings. To this end, peripheral blood and BM were isolated from JDO and B6 mice at 10 \pm 1 mo post-LD70/30 along with age-matched $\mathrm{NI}$ controls of each strain. Progenitor function, along with number and cell cycle status of various phenotypically-defined hematopoietic cells were compared. Findings in peripheral blood paralleled those discussed in Fig. 5, documenting the long-term lymphodepletion observed in B6 but not in JDO, with more severe myeloid skewing and RBC loss in B6 compared to JDO (Fig. 7a). JDO mice trended towards myeloid skewing, but this appeared to be due to enhanced neutrophil production in some IR JDO mice rather than decreased lymphopoiesis (Fig. 7a). Within the BM, NI B6 tended to have more total nucleated cells (TNC) per femur compared to NI JDO, and irradiation decreased BM cellularity in both models (Fig. 7b). Both strains possessed equivalent numbers of functional progenitors (CFU-C) at baseline, which declined significantly in B6 H-ARS survivors but not in JDOs (Fig. 7c).

To gain insight into mechanisms behind these differences in hematopoietic cell recovery in B6 versus JDO H-ARS survivors, hematopoietic stem and progenitor populations at various stages of differentiation were examined by flow cytometry. The primitive KSL population was further delineated by both CD150 and CD48 into HSC, multi-potential progenitors (MPP) and the slightly more differentiated hematopoietic progenitor cells (HPC) as shown (Fig. 7d) (Oguro et al. 2013). Of interest, while HSC number was significantly higher in NI B6 mice compared to JDO, HSC were more depleted in JDO H-ARS survivors than B6 survivors (Fig. 7e), in contrast to the pattern for CFU-C. Proliferation rates were assessed as the fraction of cells incorporating BrdU in DNA replication over a $24 \mathrm{~h}$ period prior to analysis. HSC proliferation rate was significantly increased in IR B6 compared to NI controls, as we have previously described (Chua et al. 2019), but was unchanged in IR JDO (Fig. 7f). MPP counts were also higher in B6 at baseline, while HPC counts were equivalent between NI B6 and NI JDO. In H-ARS survivors of both strains, both MPP and HPC were significantly decreased (Fig. 7e). MPP and HPC proliferation rates increased significantly in B6, and trended in the same direction in JDO but with much more variability (Fig. 7f). Thus, of the most primitive populations, phenotypic HSC differed the most between strains in $\mathrm{H}$-ARS survivors, with decreased numbers in JDO but possibly more compromised HSC function in B6.

Decreased number of committed progenitors may also result in diminished production of peripheral blood. A decrease in common lymphoid progenitors (CLP) in particular may be responsible for the long-term lymphodepletion observed in B6 but not in JDO H-ARS survivors. CLP were enriched by gating on Lin-, IL7Ra+, and intermediate cKit and Sca1 expression (Fig. 
7d) (Doulatov et al. 2012). CLP number and proliferation rate were uniformly lower in B6 H-ARS survivors and together may account for the documented decreased lymphoid output in B6 DEARE models, while deficits in CLP number and proliferation rate were less apparent in JDO (Fig. 7e-f). Committed myeloid progenitors fall within the Lin-, cKit+, Sca1- gate (KL) and were further separated by FcGR into populations enriched for granulocyte-monocyte progenitors (GMP) and for a mixture of common myeloid progenitors (CMP) and megakaryocyte-erythrocyte progenitors (MEP) (Fig. 7d) (Doulatov et al. 2012). In NI aged JDO, GMP were less abundant than in B6, and all myeloid progenitors were significantly less proliferative (Fig. 7e-f). Irradiation-related effects were minimal in the myeloid compartment (CMP, GMP, and MEP) for both mouse models, with a slight but significant increase in GMP cycling rate in B6 only. Thus, the greater long-term recovery of blood production observed in JDO survivors may stem from better maintenance of functional colony-forming progenitor cells (CFU-C), better maintenance of HSC quiescence (if not HSC number), and a less dramatic reduction in CLP number and proliferation rate long-term post-TBI. An overall summary of the JDO model compared to the B6 model for H-ARS and DEARE is compiled in Table 1. 


\section{DISCUSSION}

The work presented herein describes a new murine radiation model for H-ARS and DEARE utilizing the genetically diverse outbred JDO strain. This strain was found to be more radioresistant and more sensitive to levofloxacin mitigation than the inbred B6 strain, with less severe hematopoietic DEARE. The JDO model was validated with Neulasta, which significantly increased 30-day survival and neutrophil recovery after lethal radiation.

The enhanced radioresistance of JDO mice compared to the B6 strain was most profound at the highest radiation doses, where a difference of up to $2.32 \mathrm{~Gy}$ was noted in the estimated LD99/30 doses in JDO compared to B6 with non-overlapping 95\% confidence intervals. The higher radiation doses required for lethality may be related to the fact that some of the JDO founder strains (such as $A / J$ and B6) have been characterized as moderately to strongly radioresistant (Kohn and Kallman 1956, Mori et al. 1994). Furthermore, wild caught Mus musculus mice were also shown to have greater radioresistance compared to inbred mice (Golley et al. 1965). To our knowledge, most of the other founder strains for the JDO strain have not been analyzed for radiosensitivity. The four-week difference in age at time of irradiation may have influenced radiosensitivities between the two strains, since radiosensitivity reportedly changes with age (Crosfill et al. 1959, Spalding and Trujillo 1962). However, we have observed younger B6 mice to be more radiosensitive than young adult or geriatric B6 mice (unpublished observations), and in the studies reported herein it was the younger mice (JDO) that were more radioresistant, suggesting that age likely does not account for the observed difference in radiosensitivity. Based on these observations, further studies with JDO mice age-matched to the 12-week-old B6 model may find even greater radioresistance in JDO mice after an additional month of growth and development.

Further analysis of the large combined DRR dataset in the JDO model revealed that radiation lethality was correlated with sex, body weight, and coat color. Sex has not been shown to have a consistent effect on survival post-TBI in previous studies with inbred mice (Kohn and Kallman 1956, Plett et al. 2012), but there are sex-based differences in other radiation-induced endpoints including changes in gene and protein expression, metabolites, and genome damage (Kovalchuk et al. 2004, Inytskyy et al. 2008, Stojković et al. 2016, Jones et al. 2019). Better survival of heavier JDO mice may seem counterintuitive since smaller species tend to be more radioresistant than larger species, in part due to the rate of metabolism and cell turnover (Vriesendorp and Van Bekkum 1984). However, metabolic rates would be comparable within the same species, and increased mouse size due to adipose tissue can correlate with increased survival (Vares et al. 2014). Increased body mass index in humans also requires higher radiation 
doses to achieve efficacy (Wang et al. 2013). Regarding coat color, black mice had slightly but significantly lower 30 d survival compared to brown or white. This observation may suggest a previously unknown co-inherited trait with coat color, or coat pigment itself may be involved. However, overall survival was not different between coat colors. Interpreting these secondary observations requires caution, since the correlation of survival with weight, sex, or coat color was subtle and dependent upon a very large cohort for detection. These differences were not detectable in the smaller cohort used in the subsequent Neulasta survival study (154 mice in the Neulasta study versus 407 mice in the DRR study). Coat color was also not found to segregate with various phenotypes in previous publications using the JDO model (Churchill et al. 2004, Churchill et al. 2012, Svenson et al. 2012, Threadgill and Churchill 2012). These studies underscore that for the JDO model, like the human population, while individuals can be stratified based on a chosen phenotype like color, there is still a vast range of genotypes and phenotypes within each grouping. In this way the JDO model is different from simply utilizing multiple inbred strains; every single mouse is genetically unique, providing a continuum of possible radiation responses along a virtually all-encompassing spectrum, as opposed to a finite number of strains with genetically identical replicates.

The significant survival efficacy of Neulasta in JDO mice further validates this outbred $\mathrm{H}$ ARS model for MCM screening and efficacy studies. Neulasta significantly accelerated recovery of peripheral blood components in JDO mice, similar to other H-ARS models in non-human primates, minipigs, and inbred mice (Farese et al. 2012, Moroni et al. 2013, Chua et al. 2014). Neulasta-treated JDO survivors appeared to gain less weight during the DEARE phase than vehicle-treated or NI controls, but the high variability of this outbred strain warrants the need for a larger confirmatory study. One arm of the DRR study was executed in the presence of levofloxacin, an antibiotic recommended for prophylactic treatment of patients exposed to highdose radiation (REMM 2013). Levofloxacin significantly increased 30-day survival, overall survival time, and MST in JDO mice exposed to 8.75 Gy or greater, mirroring human observations wherein antibiotic and fluid supportive care effectively increase the LD50/60 by 2-3 Gy (Dainiak 2002, Anno et al. 2003). In B6 mice, levofloxacin was only effective at significantly increasing MST, while other antibiotics (ciprofloxacin and doxycycline in combination with neomycin) significantly increased overall survival time, MST, and, in the case of ciprofloxacin, 30-day survival also (Plett et al. 2012). It is possible that differences in antibiotic survival efficacy relates to composition of the gut microbiota. Variation in gut microbiota has been reported among inbred (Friswell et al. 2010) and outbred strains (Benson et al. 2010, Hufeldt et al. 2010), and it is well known that gut "leakage" of gastrointestinal bacteria after high dose radiation exposure can lead to systemic 
infection, as we (Plett et al. 2012) and others (Biju et al. 2012) have shown. Variation in the extent of gut leakage between B6 and JDO models could be a factor in their differential radioresistance, and this will be considered for future studies.

Utilizing BrdU incorporation, the current work confirmed our previous observations that quiescence is compromised in phenotypic HSC in irradiated B6 survivors (Chua et al. 2012, Chua et al. 2019), but found that JDO mice conversely maintain quiescence in their remaining HSC after recovery from lethal-dose irradiation. These phenotypic HSC in B6 survivors also have little or no competitive transplantation potential, indicating severely compromised function (Chua et al. 2012, Chua et al. 2019). While studies comparing long-term multi-lineage repopulation potential of HSC from irradiated B6 and JDO mice would be essential to understanding whether maintenance of HSC quiescence in irradiated JDO mice correlates with preserved HSC function, unfortunately, assessing the competitive transplantation potential of HSC from JDO mice is not possible with currently methodologies. JDO mice lack a congenic partner strain, which allows for sophisticated HSC functional studies via competitive BM transplantation. Such congenic strains are available for B6 mice. Alternatively, in vitro functional assays can assess downstream progenitor potential, and the finding herein of better retention of CFU-C activity in long-term JDO H-ARS survivors than B6 survivors correlates with improved overall hematopoietic recovery in JDO mice.

It is important to acknowledge that the unique genetic background of individual JDO mice, which makes the JDO strain a better model for human genetic diversity, also increases experimental variability, making mechanistic studies more challenging than with inbred strains but also possibly more applicable to humans. Group sizes must be increased to overcome variability and increase power in statistical analyses. The unique genetic makeup of JDO mice also opens the possibility of discovering phenotypes and mechanisms that may not be present in inbred strains, and overall represents an exciting new avenue for modeling radiation biology. 


\section{CONCLUSIONS}

In summary, this work validates the genetically diverse JDO mouse as a suitable model for $\mathrm{H}-\mathrm{ARS}$ and DEARE for efficacy testing and development of MCM against radiation according to the FDA Animal Rule. In comparison with the B6 model, JDO mice were more radioresistant, more sensitive to radiomitigation with levofloxacin, and similarly responsive to radiomitigation and accelerated $C B C$ recovery with Neulasta. Renal and cardiac DEARE were apparent in long-term H-ARS survivors, but more variable in presentation than in $B 6$ mice. Hematopoietic DEARE appeared less severe than that in B6 mice, possibly due to better maintenance of quiescence in the HSC population. In summary, this genetically diverse outbred murine model of H-ARS and DEARE is poised to effectively investigate biological responses to radiation exposure and facilitate development of novel medical countermeasures against radiation. 


\section{FIGURE LEGENDS}

Figure 1. Body weight and CBC of JDO and B6 mice. Female and male JDO ( $\mathrm{n}=256$ and 257 respectively) and B6 mice ( $n=315-317)$ were assessed for body weight at 7 and 11 weeks old respectively (a). PB was assessed for total white blood cells (WBC, b), neutrophils (NE, c), lymphocytes (LY, d), red blood cells (RBC, e), and platelets (PLT, f) at 8 weeks old (JDO, $n=35$ ) and 12 weeks old $(B 6, n=26)$. Data are mean \pm SEM; * $p<0.05$; exact $p$-value noted where 0.05 $<p<0.10$.

Figure 2. Probit plots of radiation DRR in JDO and B6 mice and effect of Levofloxacin. Male and female mice were exposed to 8.00-14.00 Gy (JDO) or 7.25-9.00 Gy (B6). Comparison of JDO and B6 DRR curves (a), and the effect of levofloxacin in autoclaved acidified drinking water and in wetted feed in JDO mice (b). JDO, $n=8-27$ mice per dose group; B6, $n=8-23$ mice per dose group. ${ }^{*} p<0.05$ vs. $B 6, \# p \leq 0.03$ vs. control group above $8.75 \mathrm{~Gy}$. Inset tables show the calculated LDXX/30 doses.

Figure 3. Hematopoietic cell characterization at d30/36 post-irradiation. Male and female JDO mice were exposed to 9.0 Gy. At d30 post-TBI, PB was assessed for WBC (a), NE (b), LY, (c), RBC (d), and PLT (e), and at d36 BM was harvested, separated by density gradient centrifugation and assessed for total low-density cells (LDBM, f), number of KSL cells per mouse (g), CD150+ cells as a percentage of KSL (h), and number of KSL150+ cells per mouse (i). $n=10-35$ for d30 $\mathrm{CBC} ; \mathrm{n}=4$ for d36 BM phenotyping; data are mean \pm SEM; * $\mathrm{p} \leq 0.05$.

Figure 4. Survival and CBC recovery of vehicle- and Neulasta-treated JDO mice following 9 Gy TBI. IR male and female JDO mice were injected subcutaneously with two doses of $1 \mathrm{mg} \mathrm{kg}^{-1}$ Neulasta or vehicle at 24-26 hours and d8 post-TBI and monitored for survival for $30 \mathrm{~d}(\mathrm{a}, \mathrm{n}=$ 52-102 mice per group, $\left.{ }^{* *} \mathrm{p}<0.001\right)$. CBC at baseline ( $\mathrm{d}-3$ or $\mathrm{d}-4, \mathrm{n}=16$ mice) and on study $\mathrm{d} 2-$ 30 from randomly selected male and female mice are shown for WBC (b), NE (c), LY (d), RBC (e), PLT (f). " $p \leq 0.01$ comparing combined data from all time points of each group, $n=4-16$ at each time point with the exception of $d 25, n=2-4$. Data are from two separate experiments.

Figure 5. Body weights, $\mathrm{CBC}$, and primitive hematopoietic BM cells of vehicle- and Neulastatreated JDO mice 6 and 12 months after lethal TBI. Male and female JDO mice were exposed to $9.0 \mathrm{~Gy}$, injected subcutaneously with 2 doses of $1 \mathrm{mg} \mathrm{kg}^{-1}$ Neulasta or vehicle at 24-26h and d8 
post-irradiation, euthanized at 6 and 12 mo post-TBI and assessed for female (a) and male (b) body weights, and total PB WBC (c), NE (d), LY (e), RBC (f), and PLT (g). $n=20-80$ mice for baseline values ( 0 , age $=2$ months), $n=4-17$ mice per group for 6 and 12 mo post-TBI time points. BM cells were assessed for total number of mononuclear cells per mouse $(\mathrm{h})$, total colony forming unit cells per mouse (CFU-C, i), number of KSL cells per mouse (KSL, j), CD150+ cells as a percentage of KSL (k), and number of KSL150+ cells per mouse (I). NI mice were analyzed noncontemporaneously with Vehicle and Neulasta mice. $n=4$ mice per group except NI CD150 analysis at 12 mo where $n=2$. Data are mean $\pm S E M ;{ }^{*} p<0.05$ comparing groups at each time point.

Figure 6. Variation in radiation-induced renal and cardiovascular pathology. Representative images are shown to illustrate the range of pathology observed in the renal cortex and left ventricle/coronary artery in terms of collagen deposition (picrosirius red, a-d), endothelial cell number or density (periodic acid-Schiff, e and f) and iron deposition (Perls' stain, blue, g-l). The left and right panels represent the minimal and worst pathology, respectively, observed in the 8 JDO mice examined at 12 mo post-TBI. Increased blood urea nitrogen (BUN) 12 mo post-TBI in vehicle (Veh)-or Neulasta (Neu)-treated mice is shown compared to age-matched $\mathrm{NI}$ mice $(\mathrm{m})$. Dotted line indicates published upper range BUN reference value for mice as described in the results.

Figure 7. Direct comparison of JDO and B6 H-ARS survivors. JDO and B6 mice at 9 and 10-11 mo post-LD70/30, respectively, were analyzed contemporaneously for CBC (a) and BM parameters (b-f) along with their age-matched NI controls. One femur per mouse was flushed and assessed for total nucleated cells (TNC) (b), CFU-C number in methylcellulose assays (c), and various precursor populations (defined in text) by multi-color flow cytometry (d). The differentiation tree shows development of HSC into committed progenitors and mature cells relevant to the CBC data (d). Precursor populations were enumerated (e) and assessed for proliferation rate by BrdU incorporation (f). Representative BrdU+ gating is shown for the HSC population (f). Data are mean \pm SEM. \#Mean and SEM not shown due to extreme outlier in the NI JDO group; note same outlier gave highest NI JDO counts for HPC, GMP, and CMP+MEP, and second highest for HSC and MPP. "\#Two samples in the DEARE JDO group had insufficient HSC for BrdU analysis. * $p<0.05$, exact $p$-value noted where $0.05<p<0.10$. 


\section{REFERENCES}

Anno GH, Young RW, Bloom RM, Mercier JR. Dose response relationships for acute ionizing-radiation lethality. Health Phys 84: 565-75; 2003.

Ashhurst TM, Cox DA, Smith AL, King NJC. Analysis of the murine bone marrow hematopoietic system using mass and flow cytometry. Methods Mol Biol 1989: 159-192; 2019.

Baverstock KF, Ash PJ. A review of radiation accidents involving whole body exposure and the relevance to the Id50/60 for man. The British journal of radiology 56: 837-44; 1983.

Benson AK, Kelly SA, Legge R, Ma F, Low SJ, Kim J, Zhang M, Oh PL, Nehrenberg D, Hua K, Kachman SD, Moriyama EN, Walter J, Peterson DA, Pomp D. Individuality in gut microbiota composition is a complex polygenic trait shaped by multiple environmental and host genetic factors. Proc Natl Acad Sci U S A 107: 18933-8; 2010.

Biju PG, Garg S, Wang W, Choudhry MA, Kovacs EJ, Fink LM, Hauer-Jensen M. Procalcitonin as a predictive biomarker for total body irradiation-induced bacterial load and lethality in mice. Shock 38: 170-6; 2012.

Cerveny T, MacVittie T, Young R. Acute radiation syndrome in humans. . Vol 2. Falls church, va: Ttm publisher; 1989:17-36. Falls Church, VA: Walker RI,. TTM; 1989.

Cheng T, Rodrigues N, Shen H, Yang Y, Dombkowski D, Sykes M, Scadden DT. Hematopoietic stem cell quiescence maintained by p21cip1/waf1. Science 287: 1804-8; 2000.

Chesler EJ. Out of the bottleneck: The diversity outcross and collaborative cross mouse populations in behavioral genetics research. Mammalian genome : official journal of the International Mammalian Genome Society 25: 3-11; 2014.

Chua HL, Plett PA, Fisher A, Sampson CH, Vemula S, Feng H, Sellamuthu R, Wu T, MacVittie TJ, Orschell $\mathrm{CM}$. Lifelong residual bone marrow damage in murine survivors of the hematopoietic acute radiation syndrome ( $\mathrm{h}$-ars): A compilation of studies comprising the indiana university experience. Health Phys 116: 546-557; 2019.

Chua HL, Plett PA, Sampson CH, Joshi M, Tabbey R, Katz BP, MacVittie TJ, Orschell CM. Long-term hematopoietic stem cell damage in a murine model of the hematopoietic syndrome of the acute radiation syndrome. Health Phys 103: 356-66; 2012.

Chua HL, Plett PA, Sampson CH, Katz BP, Carnathan GW, MacVittie TJ, Lenden K, Orschell CM. Survival efficacy of the pegylated g-csfs maxy-g34 and neulasta in a mouse model of lethal h-ars, and residual bone marrow damage in treated survivors. Health Phys 106: 21-38; 2014.

Churchill GA, Airey DC, Allayee H, Angel JM, Attie AD, Beatty J, Beavis WD, Belknap JK, Bennett B, Berrettini W, Bleich A, Bogue M, Broman KW, Buck KJ, Buckler E, Burmeister M, Chesler EJ, Cheverud JM, Clapcote S, Cook MN, Cox RD, Crabbe JC, Crusio WE, Darvasi A, Deschepper CF, Doerge RW, Farber CR, Forejt J, Gaile D, Garlow SJ, Geiger H, Gershenfeld H, Gordon T, Gu J, Gu W, de Haan G, Hayes NL, Heller C, Himmelbauer H, Hitzemann R, Hunter K, Hsu HC, Iraqi FA, Ivandic $B$, Jacob HJ, Jansen RC, Jepsen KJ, Johnson DK, Johnson TE, Kempermann G, Kendziorski C, Kotb M, Kooy RF, Llamas B, Lammert F, Lassalle JM, Lowenstein PR, Lu L, Lusis A, Manly KF, Marcucio R, Matthews D, Medrano JF, Miller DR, Mittleman G, Mock BA, Mogil JS, Montagutelli X, Morahan G, Morris DG, Mott R, Nadeau JH, Nagase H, Nowakowski RS, O'Hara BF, Osadchuk AV, Page GP, Paigen B, Paigen K, Palmer AA, Pan HJ, Peltonen-Palotie L, Peirce J, Pomp D, Pravenec M, Prows DR, Qi Z, Reeves RH, Roder J, Rosen GD, Schadt EE, Schalkwyk LC, Seltzer Z, Shimomura K, Shou S, Sillanpaa MJ, Siracusa LD, Snoeck HW, Spearow JL, Svenson K, Tarantino LM, Threadgill D, Toth LA, Valdar W, de Villena FP, Warden C, Whatley S, Williams RW, Wiltshire $\mathrm{T}$, Yi N, Zhang D, Zhang M, Zou F. The collaborative cross, a community resource for the genetic analysis of complex traits. Nat Genet 36: 1133-7; 2004. 
Churchill GA, Gatti DM, Munger SC, Svenson KL. The diversity outbred mouse population. Mammalian genome : official journal of the International Mammalian Genome Society 23: 713-8; 2012.

Collaborative Cross $C$. The genome architecture of the collaborative cross mouse genetic reference population. Genetics 190: 389-401; 2012.

Crawford L. New drug and biological drug products; evidence needed to demonstrate effectiveness of new drugs when human efficacy studies are not ethical or feasible. 21 CFR parts 314 and 601, FDA, HHS; ACTION: Final Rule: 37988-37998; 2002.

Crosfill ML, Lindop PJ, Rotblat J. Variation of sensitivity to ionizing radiation with age. Nature 183: 172930; 1959.

Dainiak N. Hematologic consequences of exposure to ionizing radiation. Exp Hematol 30: 513; 2002.

Doulatov S, Notta F, Laurenti E, Dick JE. Hematopoiesis: A human perspective. Cell Stem Cell 10: 120-36; 2012.

Farese A, Cohen M, Stead R, Jackson III W, MacVittie T. Peg-filgrastim, administered in an abbreviated schedule, significantly improved neutrophil recovery after high-dose, radiation-induced meylosuppression in rhesus macaques. Radiat Res 178: 403-413; 2012.

Farese AM, Cohen MV, Katz BP, Smith CP, Jackson W, 3rd, Cohen DM, MacVittie TJ. A nonhuman primate model of the hematopoietic acute radiation syndrome plus medical management. Health Phys 103: 367-82; 2012.

Farese AM, Hankey KG, Cohen MV, MacVittie TJ. Lymphoid and myeloid recovery in rhesus macaques following total body x-irradiation. Health Phys 109: 414-26; 2015.

Friswell MK, Gika H, Stratford IJ, Theodoridis G, Telfer B, Wilson ID, McBain AJ. Site and strain-specific variation in gut microbiota profiles and metabolism in experimental mice. PLoS One 5: e8584; 2010.

Frith $\mathrm{CH}$, Suber RL, Umholtz R. Hematologic and clinical chemistry findings in control balb/c and c57bl/6 mice. Lab Anim Sci 30: 835-40; 1980.

Golley FB, Gentry JB, Menhinick EF, Carmon JL. Response of wild rodents to acute gamma radiation. Radiation Research 24: 350-356; 1965.

Hao S, Chen C, Cheng T. Cell cycle regulation of hematopoietic stem or progenitor cells. Int J Hematol 103: 487-97; 2016.

Hufeldt MR, Nielsen DS, Vogensen FK, Midtvedt T, Hansen AK. Variation in the gut microbiota of laboratory mice is related to both genetic and environmental factors. Comparative medicine 60: 336-47; 2010.

Ilnytskyy Y, Zemp FJ, Koturbash I, Kovalchuk O. Altered microrna expression patterns in irradiated hematopoietic tissues suggest a sex-specific protective mechanism. Biochem Biophys Res Commun 377: 41-5; 2008.

Jones JW, Alloush J, Sellamuthu R, Chua HL, MacVittie TJ, Orschell CM, Kane MA. Effect of sex on biomarker response in a mouse model of the hematopoietic acute radiation syndrome. Health Phys 116: 484-502; 2019.

Kohn $\mathrm{H}$, Kallman K. The influence of strain on acute x-ray lethality in the mouse. I. $\mathrm{Ld}_{50}$ and death rate studies. Radiation Res 5: 309-317; 1956.

Kovalchuk O, Burke P, Besplug J, Slovack M, Filkowski J, Pogribny I. Methylation changes in muscle and liver tissues of male and female mice exposed to acute and chronic low-dose x-ray-irradiation. Mutation research 548: 75-84; 2004.

Logan RW, Robledo RF, Recla JM, Philip VM, Bubier JA, Jay JJ, Harwood C, Wilcox T, Gatti DM, Bult CJ, Churchill GA, Chesler EJ. High-precision genetic mapping of behavioral traits in the diversity outbred mouse population. Genes, brain, and behavior 12: 424-37; 2013. 
MacVittie TJ, Bennett AW, M VC, Farese AM, Higgins A, Hankey KG. Immune cell reconstitution after exposure to potentially lethal doses of radiation in the nonhuman primate. Health Phys 106: 8496; 2014.

Mori N, Okumoto M, Yonezawa M, Nishikawa R, Takamori Y, Esaki K. Factors related to resistance to hematopoietic death in mice. J Radiat Res (Tokyo) 35: 1-10; 1994.

Moroni M, Ngudiankama BF, Christensen C, Olsen CH, Owens R, Lombardini ED, Holt RK, Whitnall MH. The gottingen minipig is a model of the hematopoietic acute radiation syndrome: G-colony stimulating factor stimulates hematopoiesis and enhances survival from lethal total-body gamma-irradiation. Int J Radiat Oncol Biol Phys 86: 986-92; 2013.

Morton NM, Beltram J, Carter RN, Michailidou Z, Gorjanc G, McFadden C, Barrios-Llerena ME, Rodriguez-Cuenca S, Gibbins MT, Aird RE, Moreno-Navarrete JM, Munger SC, Svenson KL, Gastaldello A, Ramage L, Naredo G, Zeyda M, Wang ZV, Howie AF, Saari A, Sipila P, Stulnig TM, Gudnason V, Kenyon CJ, SeckI JR, Walker BR, Webster SP, Dunbar DR, Churchill GA, Vidal-Puig A, Fernandez-Real JM, Emilsson V, Horvat S. Genetic identification of thiosulfate sulfurtransferase as an adipocyte-expressed antidiabetic target in mice selected for leanness. Nat Med 22: 771-9; 2016.

Niazi MK, Dhulekar N, Schmidt D, Major S, Cooper R, Abeijon C, Gatti DM, Kramnik I, Yener B, Gurcan M, Beamer $G$. Lung necrosis and neutrophils reflect common pathways of susceptibility to mycobacterium tuberculosis in genetically diverse, immune-competent mice. Disease models \& mechanisms 8: 1141-53; 2015.

Oguro H, Ding L, Morrison SJ. Slam family markers resolve functionally distinct subpopulations of hematopoietic stem cells and multipotent progenitors. Cell Stem Cell 13: 102-16; 2013.

Park HR, Jo SK, Jung U, Yee ST, Kim SH. Protective effects of hemohim on immune and hematopoietic systems against gamma-irradiation. Phytotherapy research : PTR 28: 245-51; 2014.

Plett PA, Chua HL, Sampson CH, Katz BP, Fam CM, Anderson L, Cox G, Orschell CM. Pegylated g-csf (bbt015), gm-csf (bbt-007), and il-11 (bbt-059) analogs enhance survival and hematopoietic cell recovery in a mouse model of the hematopoietic syndrome of the acute radiation syndrome. Health physics 106: 7-20; 2014.

Plett PA, Sampson CH, Chua HL, Jackson W, Vemula S, Sellamuthu R, Fisher A, Feng H, Wu T, MacVittie TJ, Orschell CM. The h-ars dose response relationship (drr): Validation and variables. Health Phys 109: 391-8; 2015.

Plett PA, Sampson CH, Chua HL, Joshi M, Booth C, Gough A, Johnson CS, Katz BP, Farese AM, Parker J, MacVittie TJ, Orschell CM. Establishing a murine model of the hematopoietic syndrome of the acute radiation syndrome. Health Phys 103: 343-55; 2012.

Recla JM, Robledo RF, Gatti DM, Bult CJ, Churchill GA, Chesler EJ. Precise genetic mapping and integrative bioinformatics in diversity outbred mice reveals hydin as a novel pain gene. Mammalian genome : official journal of the International Mammalian Genome Society 25: 21122; 2014.

REMM. Prototype for adult and pediatric medical orders during a radiation incident [online]. Available at: http://www.remm.nlm.gov/adultorderform.htm.

Roberts A, Pardo-Manuel de Villena F, Wang W, McMillan L, Threadgill DW. The polymorphism architecture of mouse genetic resources elucidated using genome-wide resequencing data: Implications for qtl discovery and systems genetics. Mammalian genome : official journal of the International Mammalian Genome Society 18: 473-81; 2007.

Simonnet AJ, Nehme J, Vaigot P, Barroca V, Leboulch P, Tronik-Le Roux D. Phenotypic and functional changes induced in hematopoietic stem/progenitor cells after gamma-ray radiation exposure. Stem Cells 27: 1400-9; 2009. 
Singh VK, Seed TM. Pharmacological management of ionizing radiation injuries: Current and prospective agents and targeted organ systems. Expert Opin Pharmacother 21: 317-337; 2020.

Spalding JF, Trujillo TT. Radiosensitivity of mice as a function of age. Radiat Res 16: 125-9; 1962.

Stojković R, Fucic A, Ivanković D, Jukić Z, Radulović $P$, Grah J, Kovačević N, Barišić L, Krušlin B. Age and sex differences in genome damage between prepubertal and adult mice after exposure to ionising radiation. Arh Hig Rada Toksikol 67: 297-303; 2016.

Svenson KL, Gatti DM, Valdar W, Welsh CE, Cheng R, Chesler EJ, Palmer AA, McMillan L, Churchill GA. High-resolution genetic mapping using the mouse diversity outbred population. Genetics 190: 437-47; 2012.

Threadgill DW, Churchill GA. Ten years of the collaborative cross. G3 (Bethesda, Md) 2: 153-6; 2012.

Unthank JL, Miller SJ, Quickery AK, Ferguson EL, Wang M, Sampson CH, Chua HL, DiStasi MR, Feng H, Fisher A, Katz BP, Plett PA, Sandusky GE, Sellamuthu R, Vemula S, Cohen EP, MacVittie TJ, Orschell CM. Delayed effects of acute radiation exposure in a murine model of the h-ars: Multiple-organ injury consequent to <10 gy total body irradiation. Health Phys 109: 511-21; 2015.

Unthank JL, Ortiz M, Trivedi H, Pelus LM, Sampson CH, Sellamuthu R, Fisher A, Chua HL, Plett A, Orschell $\mathrm{CM}$, Cohen EP, Miller SJ. Cardiac and renal delayed effects of acute radiation exposure: Organ differences in vasculopathy, inflammation, senescence and oxidative balance. Radiat Res 191: 383-397; 2019.

Vares G, Wang B, Ishii-Ohba H, Nenoi M, Nakajima T. Diet-induced obesity modulates epigenetic responses to ionizing radiation in mice. PLoS One 9: e106277; 2014.

Vriesendorp H, Van Bekkum D. Susceptibility to total-body irradiation. In: J Broerse, T MacVitties eds. Response of different species to total body irradiaton. Amsterdam: Martinus Nijhoff; 1984.

Wang AJ, Goldsmith ZG, Wang C, Nguyen G, Astroza GM, Neisius A, Iqbal MW, Neville AM, Lowry C, Toncheva G, Yoshizumi TT, Preminger GM, Ferrandino MN, Lipkin ME. Obesity triples the radiation dose of stone protocol computerized tomography. The Journal of Urology 189: 21422146; 2013. 
Table 1. Comparison of C67BL/6J and JDO as models for H-ARS and DEARE

\section{\begin{tabular}{l} 
Model Feature \\
\hline Genetic Diversity \\
Levofloxacin Mitigation:
\end{tabular}}

30-day survival Overall survival time Mean survival time

G-CSF Mitigation

DRR:

Slope
LD30/30
LD50/30
LD70/30
LD90/30

PB 30 d post-TBI:

$\begin{array}{rcc}\text { LY } & \text { Low } & \text { Low } \\ \text { NE } & \text { Low-Normal } & \text { Normal } \\ \text { RBC } & \text { Low-Normal } & \text { Normal } \\ \text { PLT } & \text { Low-Normal } & \text { Normal }\end{array}$

Yes

1.02
8.54
9.00
9.48
10.31

2.56

8.34

8.53

8.72

9.04

No
No
Yes

Yes
Yes, >8.50 Gy
Yes, >8.75 Gy
Yes, >8.50 Gy

\section{Figure and References}

(Collaborative Cross 2012)

Fig. 2b; (Plett et al. 2012)

Fig. 4a; (Chua et al. 2014, Plett et al. 2014)

Fig. 2a

Fig. 3a; Fig.4c-f; (Plett et al. 2012, Park et al. 2014, Plett et al. 2014, Chua et al. 2019)

Fig. 5d-g; Fig. 7a; (Chua et al. 2019)

$$
\text { Myeloid Skew }
$$

\section{BM 6-12 mo post-TBI:}

Number

$\begin{array}{rrc} & \text { CFU-C } & \text { Low } \\ \text { GMP } & \text { Normal } \\ \text { CMP+MEP } & \text { Normal } \\ \text { CLP } & \text { Low } \\ \text { HPC } & \text { Low } \\ \text { MPP } & \text { Low } \\ \text { HSC } & \text { Low-Normal } \\ \text { Proliferation rates } & \text { GMP } & \text { High } \\ \text { CMP+MEP } & \text { Normal } \\ & \text { CLP } & \text { Low } \\ \text { HPC } & \text { High } \\ \text { MPP } & \text { High } \\ \text { HSC } & \text { High }\end{array}$

\section{Normal Normal-High Low-Normal Low-Normal No}

\begin{tabular}{c|} 
Low \\
Low-Normal \\
Normal \\
Normal \\
Low-Normal \\
Low \\
Low \\
Low
\end{tabular}

Normal Normal Low-Normal High-Normal High-Normal Normal
Fig. 5i-1; Fig. 7b-e; (Chua et al. 2019)

Fig. $7 f$ 
Figure 1
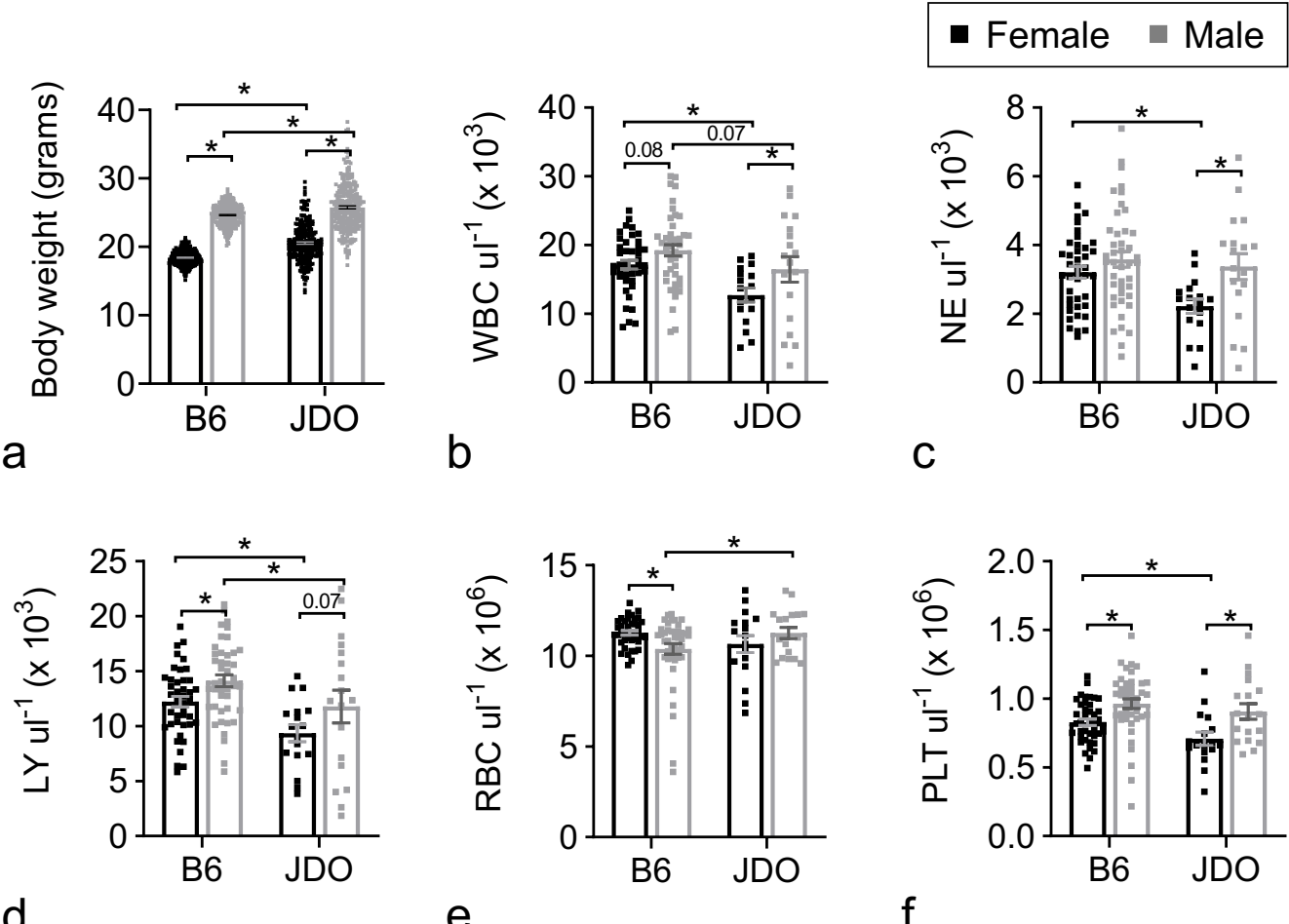

d

e

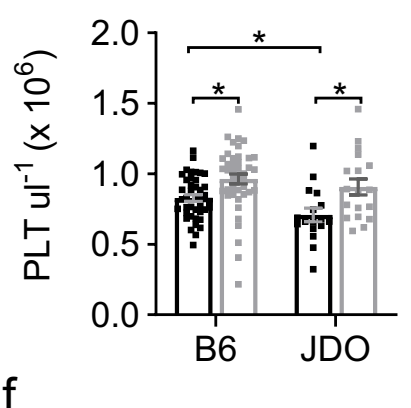


Figure 2
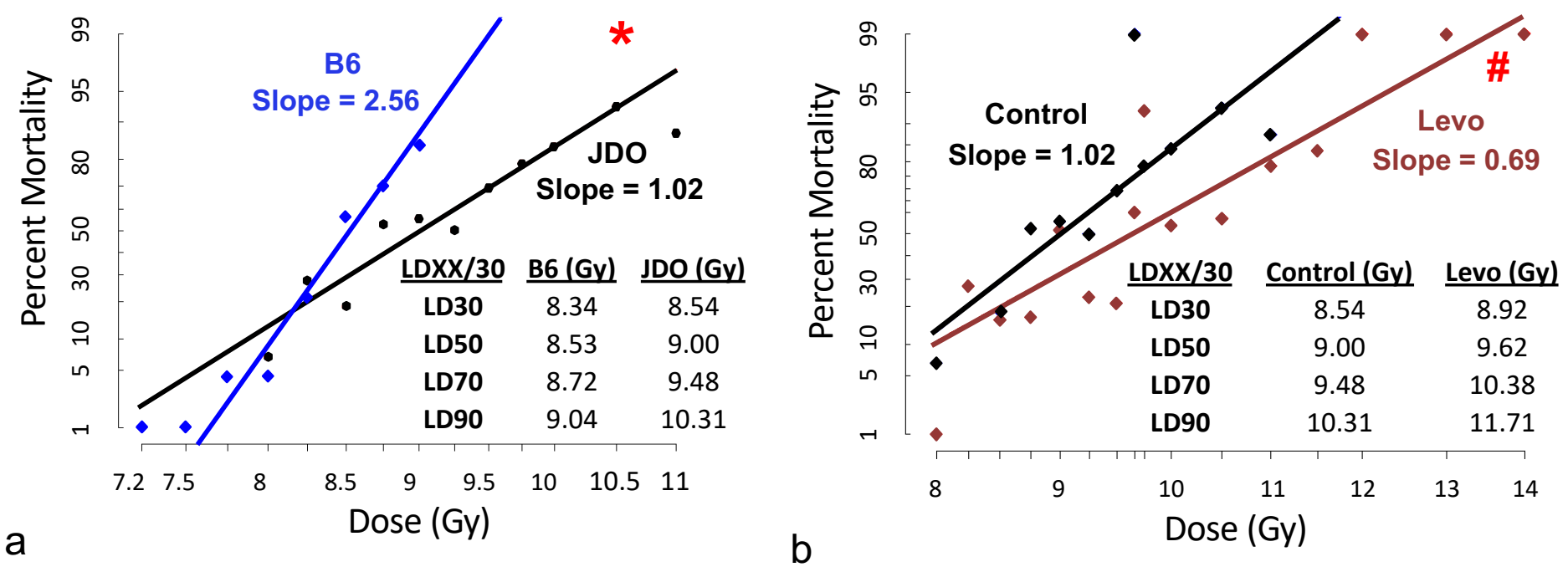
Figure 3

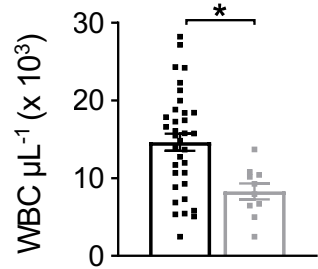

a

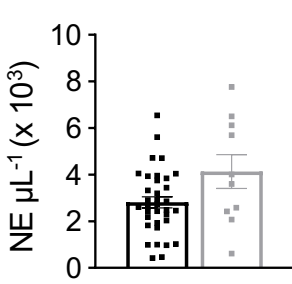

b

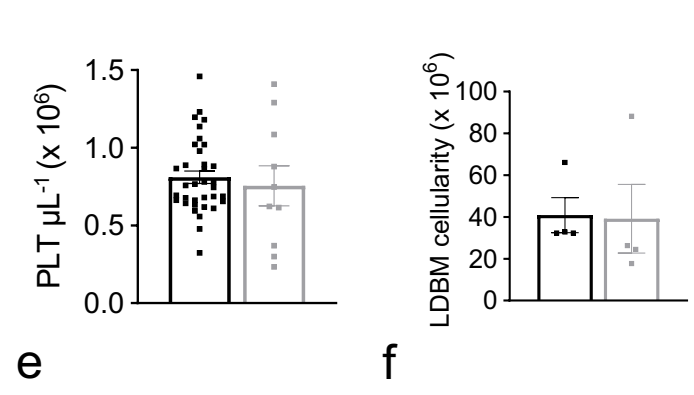

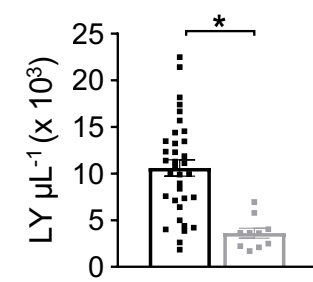

C
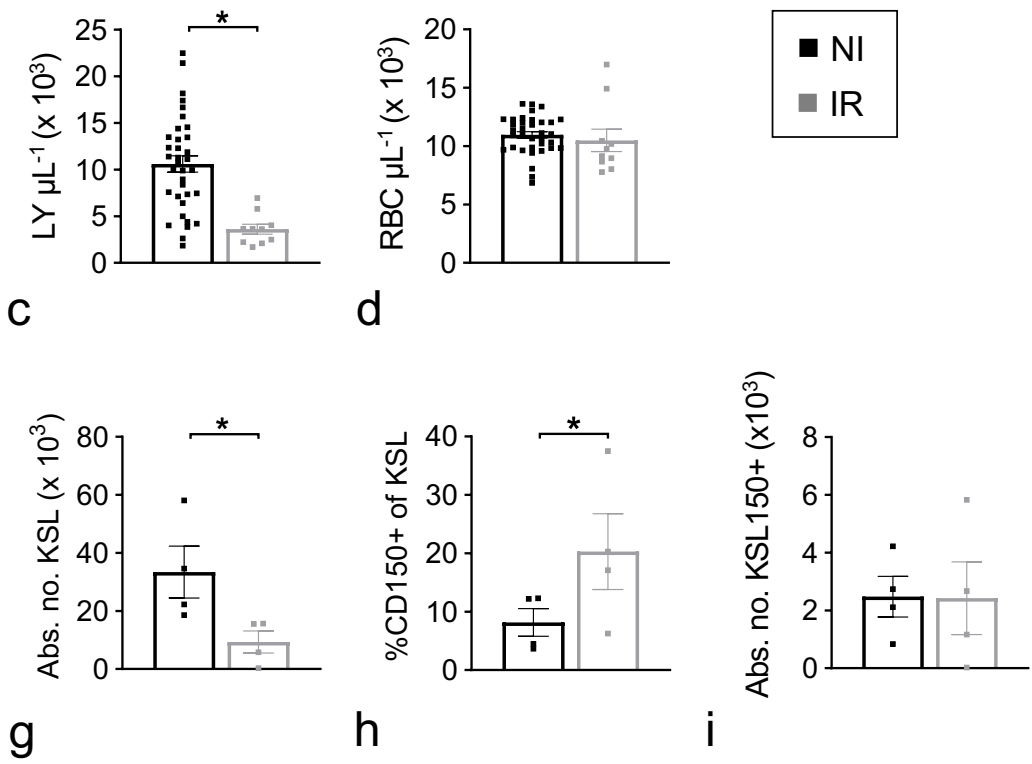
Figure 4
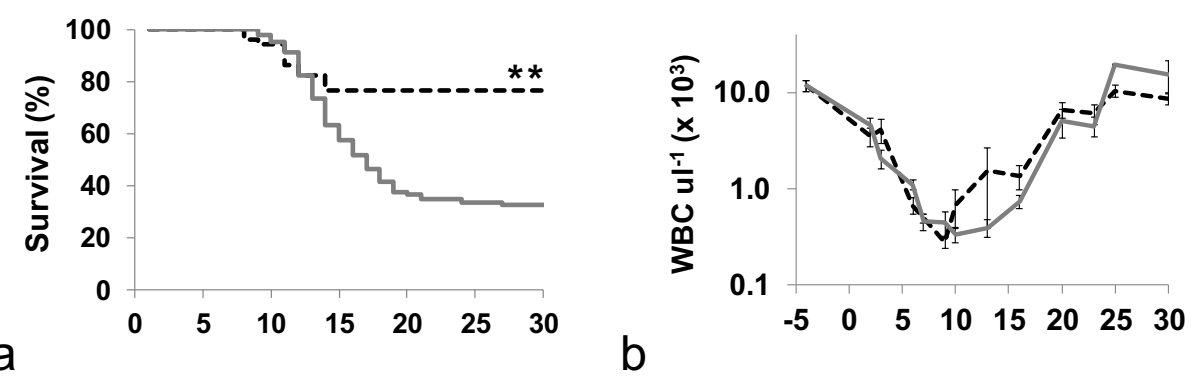

IR-Vehicle --- IR-Neulasta
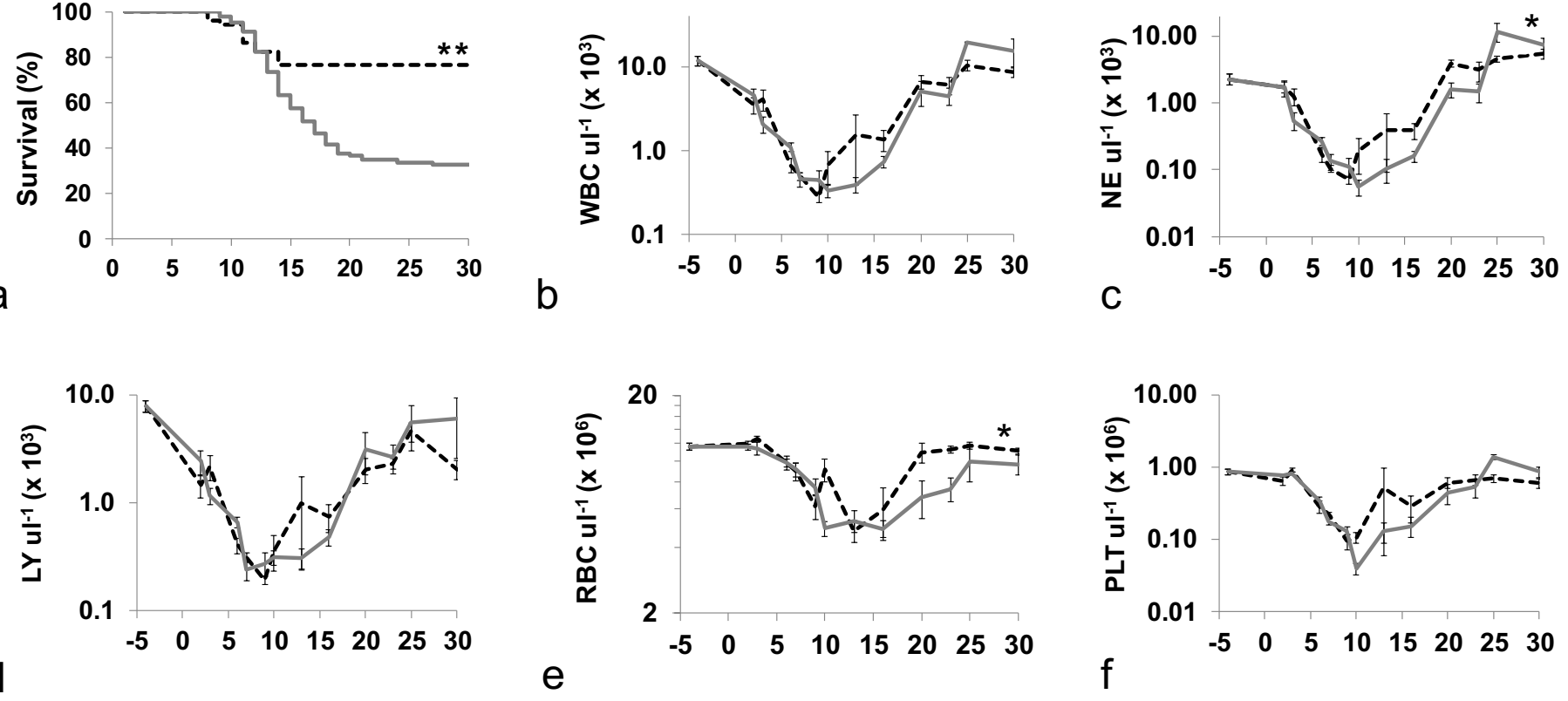

d 
Figure 5
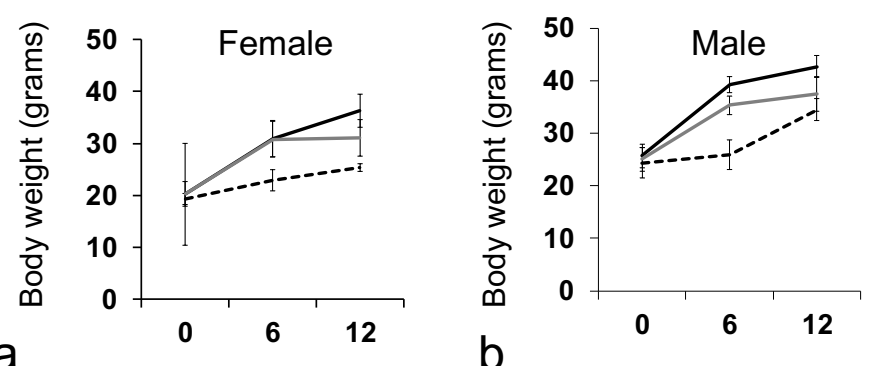

b
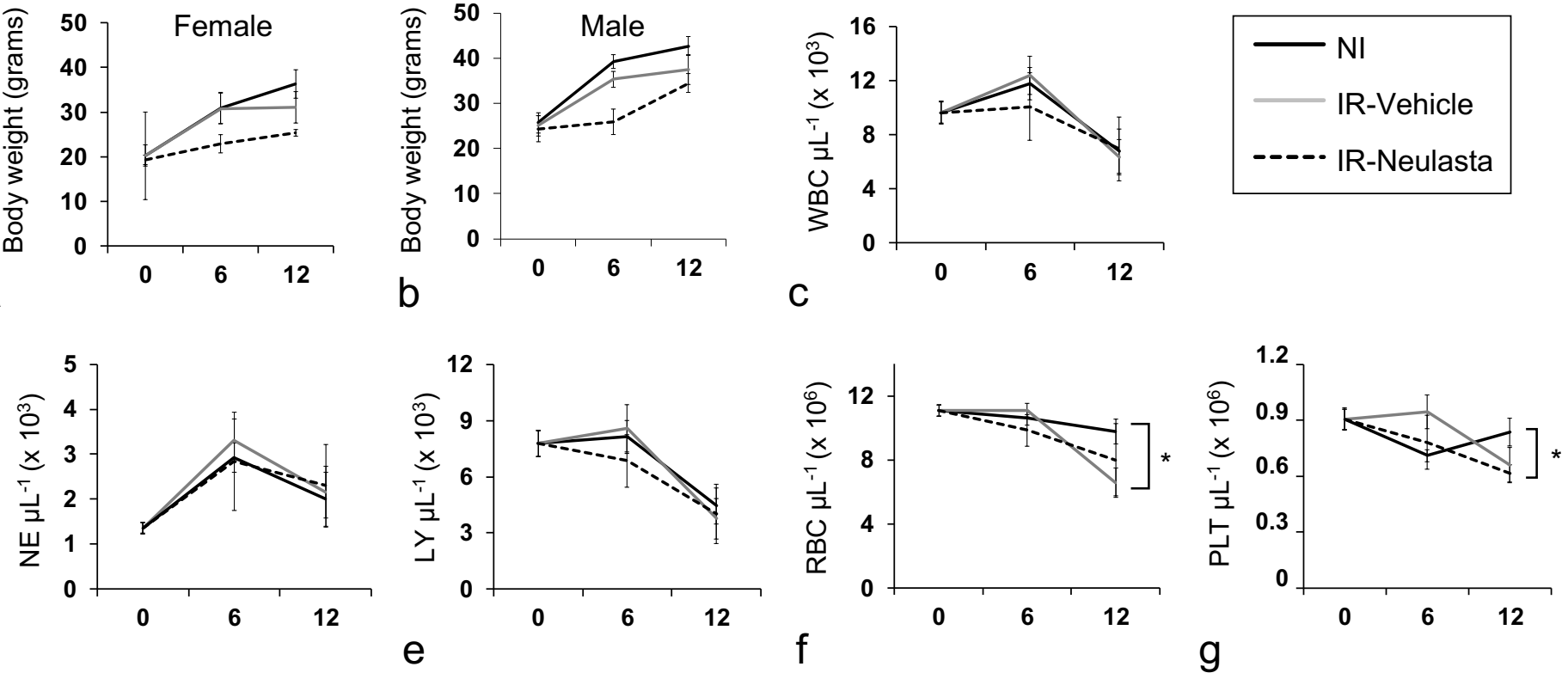

\begin{tabular}{|ll}
\hline $\mathrm{NI}$ \\
\hline
\end{tabular}
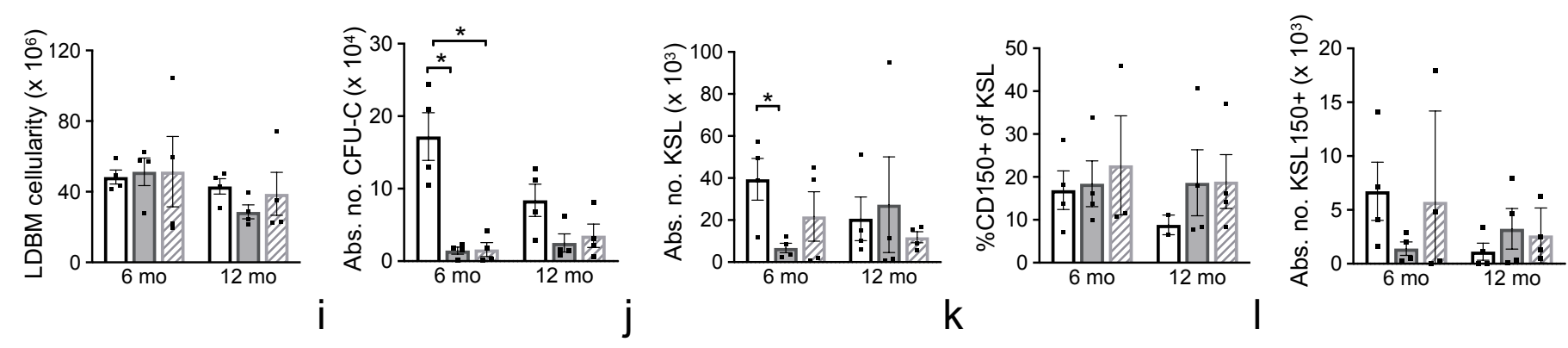

Months post-TBI 
Figure 6

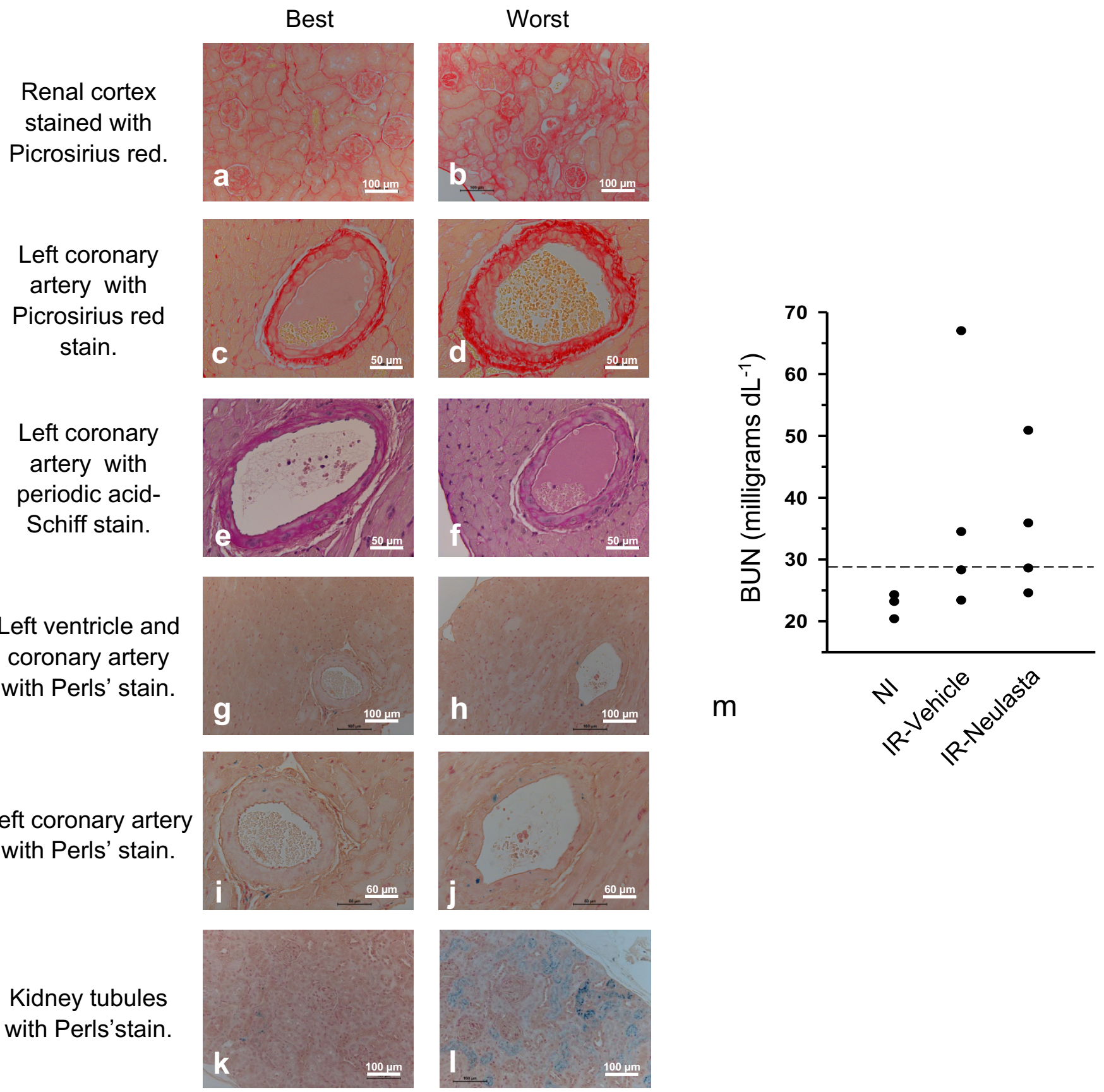


Figure 7
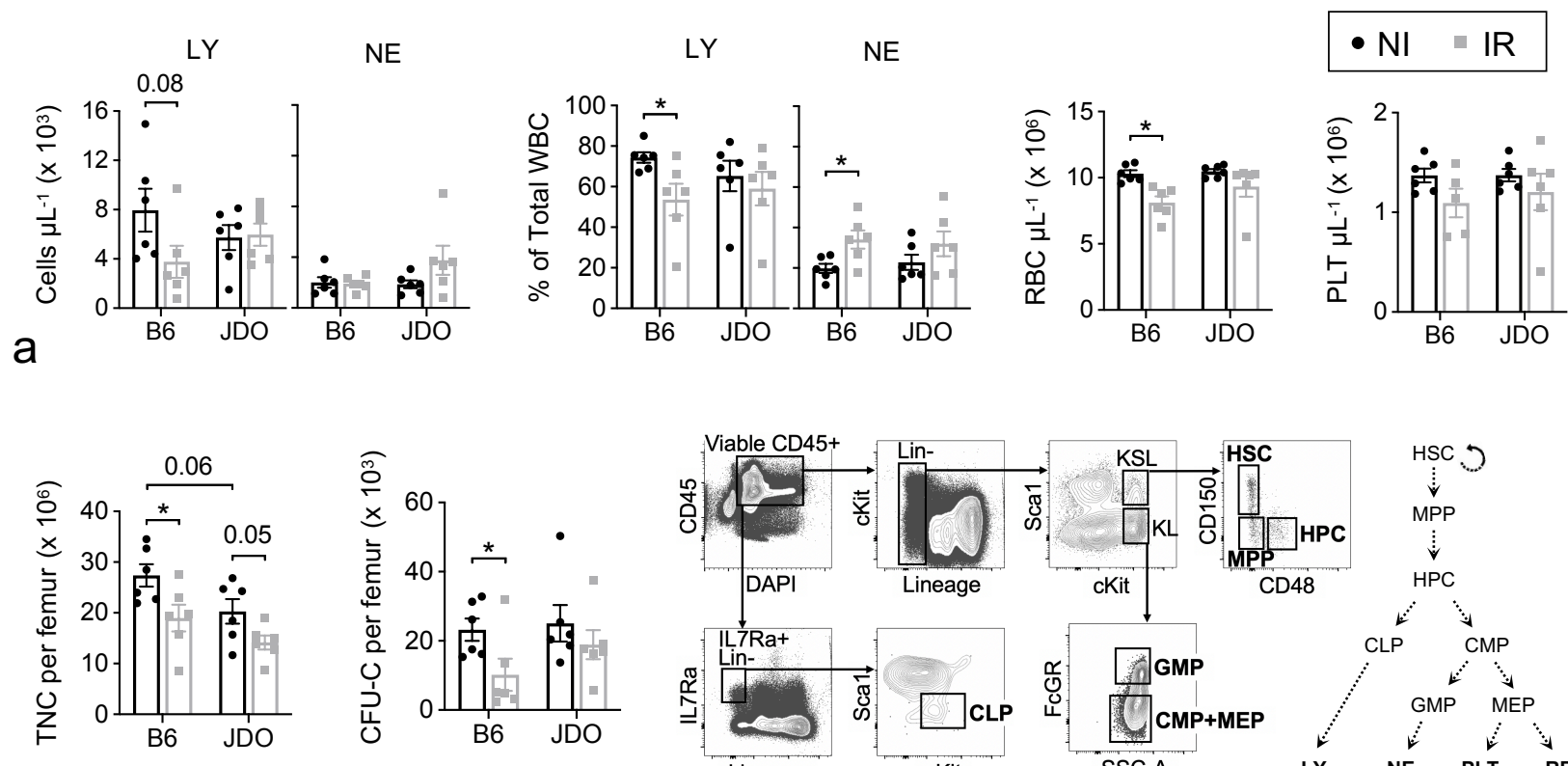

b

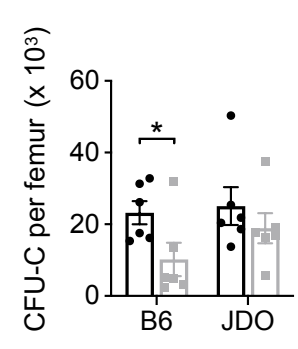

C

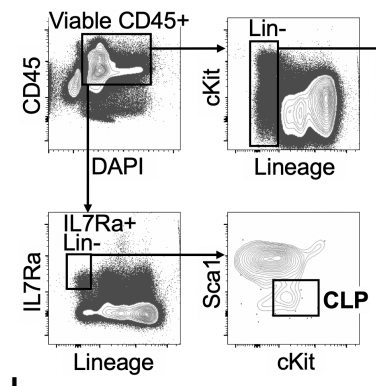

d
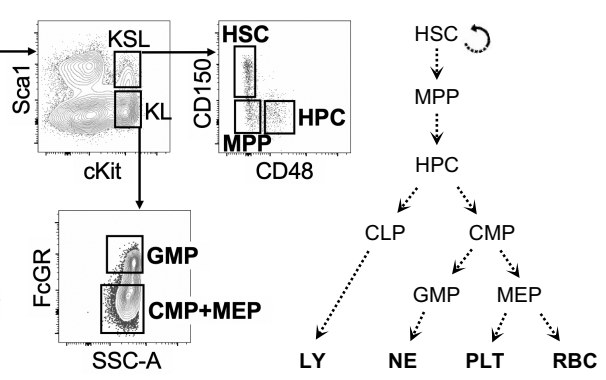

HPC

CLP

GMP

CMP+MEP
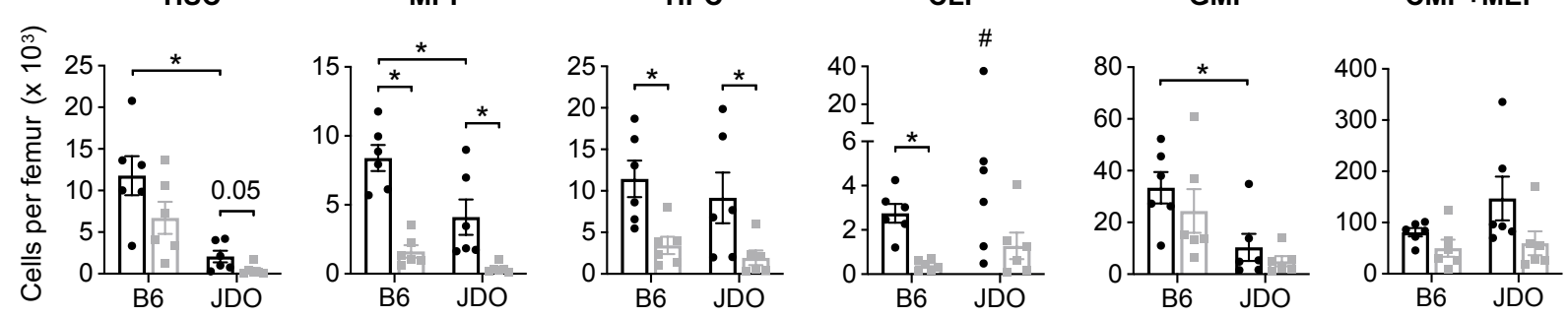

e

HSC
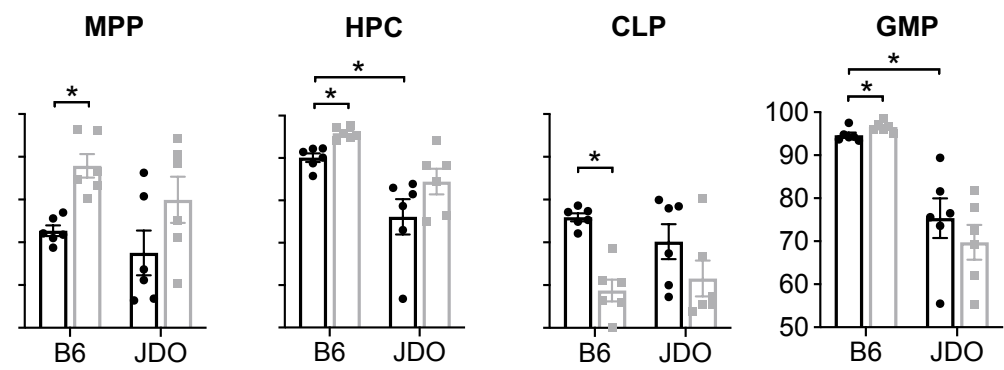

CMP+MEP
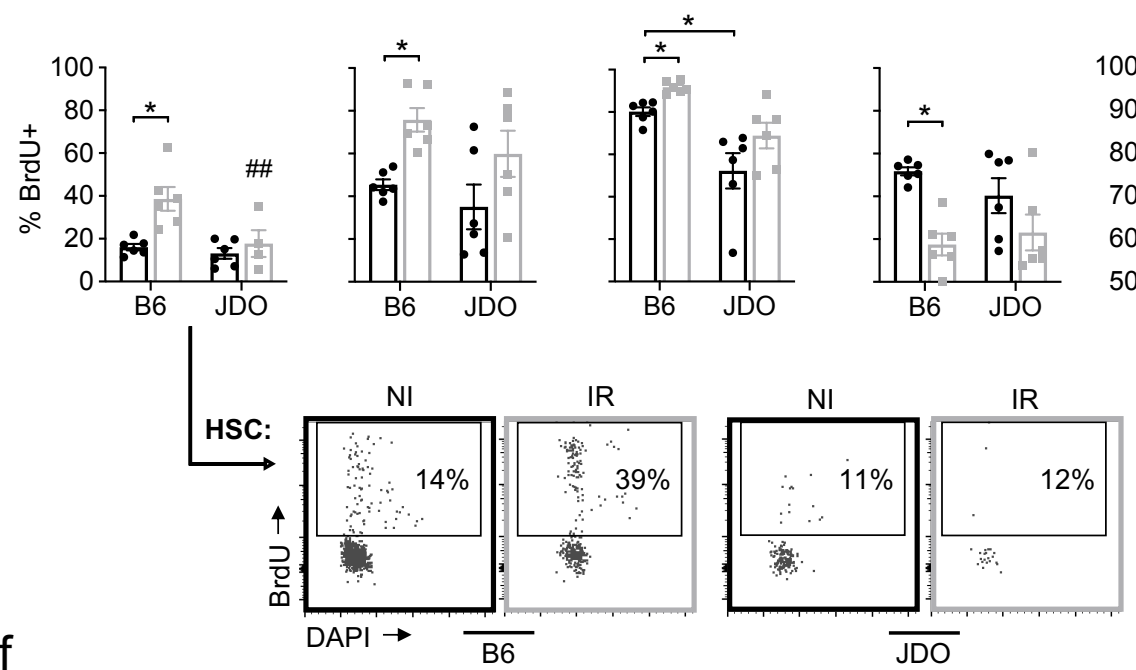